\title{
RESEARCH NOTE \\ Estimation of the lifespan of agricultural tractor using a diffusion model at the aggregate level
}

\author{
Ricardo Muñoz ${ }^{1}$ and José Llanos ${ }^{2}$ \\ ${ }^{1}$ Facultad de Economía y Empresa, Universidad Diego Portales, Ave. Manuel Rodríguez Sur 415. Santiago, \\ Chile. \\ ${ }^{2}$ Universidad de Santiago de Chile. Ave. Ecuador 3769. Santiago, Chile.
}

\begin{abstract}
R. Muñoz, and J. Llanos. 2012. Estimation of the lifespan of agricultural tractor using a diffusion model at the aggregate level. Cien. Inv. Agr. 39(3): 557-562. The adoption of agricultural tractors by farms has resulted in different combinations, relationships and established ways of production of localities, regions and countries. The dynamics of the tractorization process are defined by the balance of the units that enter the fleet and those that are removed at the end of their useful life. This study uses a diffusion pattern and aggregated adoption of the agricultural tractor, the parameters of which were determined using a nonlinear estimation procedure and country-level data for Chile. Using the predictive power of the model, a longitudinal series of tractor fleets was estimated, and then the balance was calculated considering the units that were discharged. To more accurately determine the average lifespan of a tractor, successive iterations were performed to reduce differences with respect to a control variable for the number of tractors registered. The estimated average lifespan for agricultural tractors at the aggregate level is 22 years. This type of estimation procedure can be used not only for descriptive purposes, as in this case, but also for predictive purposes.
\end{abstract}

Key words: Aggregate diffusion, agricultural mechanization, lifespan, technology adoption, tractor, tractorization.

\section{Introduction}

The adoption of tractors on farms has resulted in different combinations, relationships and established ways of production of localities, regions and countries. Many researchers have examined the agricultural tractor from different perspectives, including the choice between tractor and animal

Received January 29, 2012. Accepted July 11, 2012. Corresponding author: ricardo.munozc@mail.udp.cl traction (Olmstead and Rhode, 2001); the factors affecting economic evaluation of agricultural tractors (Hetz et al.,1998); the costs, in terms of opportunity, time savings and improvements in the implementation of technology adoption (Duffy and Silberberg, 2006); the demand projection of tractors (Unakitan and Akdemir, 2007); the positive growth rate of tractors and its relationship to technological change (Hussain and Ali, 1989; Patel and Madalsa, 1996); the use of tractors as an indicator of prosperity or progress in the agricultural sector (Unakitan 
and Akdemir, 2007); valuation and depreciation models for tractors (Guadalajara-Olmeda and Fenollosa-Ribera, 2010) and the relationship between tractor stock and adoption and diffusion patterns (Muñoz et al., 2011). In these studies, the useful life or lifespan of the tractor parameter plays an important role in the analysis. This parameter is often given or assumed, and influences the estimation of important technical and economic variables (Hetz et al.,1998; Unakitan and Akdemir, 2007; Guadalajara-Olmeda and Fenollosa-Ribera, 2010; Muñoz et al. 2011).

Most aggregate adoption models are analytically derived from the behavior of the diffusion process over time, with the analytical characteristics of that behavior being tied to the nature of the model (Rao and Kishore, 2010). Aggregate adoption models have their origin in the growth approach (Baptista, 1999), which has been adapted for various applications (Mahajan et al., 2000; Singh, 2008, Tseng and $\mathrm{Hu}, 2009$ ) including tractors (Muñoz et al., 2011). The results show a temporal pattern of adoption, the graph of which is an S-shape or sigmoidal curve.

Muñoz et al. (2011) proposed a descriptive model based on tractorization in Chile that can be used as a space-time reference structure for the diffusion and adoption of technology in place studies of technical change, social development and economic development in a country. The same study estimated the tractorization plan at an aggregate level, based on the logistic growth paradigm.

The objective of this study was to estimate the average lifespan of a tractor at the aggregate level using an aggregate diffusion model and the balance of the tractor fleet, based on the information described by Muñoz et al. (2011). This model can be used to describe the process and also to estimate a longitudinal series of the tractor fleet. Then, when the tractor's estimated useful life is known, through the estimation of discharged units, a fleet balance is achievable. The model can then be used to re-evaluate the value given as the average lifespan of the tractor, through successive iterations, to reduce the differences with respect to a given control variable, such as the annual series of tractors registered.

\section{Materials and methods}

The balance of the tractor fleet was taken from the model developed by Muñoz et al. (2011).

To estimate the tractor fleet at any given time, the following expression was used:

$$
P_{t}^{T}-P_{t-1}^{T}=T_{t}^{N}-T_{t}^{R}
$$

The balance at time $t$ (year) is given by the following expression:

$P_{t}^{T}-P_{t-1}^{T}=T_{t}^{N}-T_{t}^{R}$

where:

$P_{t}^{T}=$ Number of tractors at time $\mathrm{t}$

$P_{t-1}^{T}=$ Number of tractors at time t-1

$T_{t}^{N}=$ Number of tractors to be added to the fleet at time $\mathrm{t}$

$T_{t}^{R}=$ Number of tractors that leave the fleet at time t.

\section{Aggregate adoption model}

To determine the growth rate of the tractorization process or the distribution and adoption of the tractor, Muñoz et al. (2011) used a nonlinear procedure, and based on the Marquardt method (Rawlings et al., 1998), the following expression was obtained:

$P^{T}=54,799.2(1+\exp (-(-3.48444+0.0849665 * t)))$ 


\section{Data source}

The number of registered tractors was obtained from the Registro Nacional de Vehículos Motorizados (RNVM, Chile), which provides information from 1985 on. This series included units between 1987 and 1997, selected to exclude the cumulative number observed in the initial years and to consider the agricultural census of 1997 ( $n=49,967$ tractors), because these were the latest data used in developing equation (2).

\section{Estimates}

Muñoz et al. (2011) indicated that the number of tractors discharged from the fleet $\left(T^{R}\right)$ can be estimated by knowing the average lifespan of a tractor, while knowing the number of tractors to be incorporated $\left(T^{N}\right)$ requires knowing the number of annual registrations of new tractors or units sold in the market. The difficulty in determining $T^{R}{ }_{t}$ lies in the fact that different final figures will be obtained depending on the selected lifespan, while for $T^{N}$, rigorous statistics kept by the vehicle registration or import entities or vendors are required. The agricultural census data (Dirección General de Estadística, 1933; Dirección General de Estadística, 1938; SNEC, 1955; Dirección de
Estadística y Censos, 1969; INE, 1976; INE, 1997) offer a way to overcome the difficulties mentioned because they represent the actual number of tractors $\left(P_{t}^{T}\right)$. Therefore, the choice was made to use the growth curve described by expression (2) for the period between 1930 and 1997. The graph is shown in Figure 1.

Afterward and also at the aggregate level, the tractor fleet $\left(P^{T}\right)$ was assessed: $P^{T}$ t- was determined, and equation (1) was applied to estimate the number of tractors that were added to the fleet, assuming in the equation an average lifespan ranging from 10 to 30 years. Then, the variance between the estimated number and the series values was determined from the number of tractors registered. The deviation of the estimate was expressed as absolute error (\%).

\section{Results and discussion}

Based on the procedure used in this study, an average useful life of 22 years yielded the lowest average absolute error (19.4\%). The absolute error decreased from 30.4 to $19.4 \%$ as the average life increased from 10 and 22 years, and the absolute error increased from 19.4 to $26.2 \%$ as the average life increased from 22 and 30 years (Figure 2).

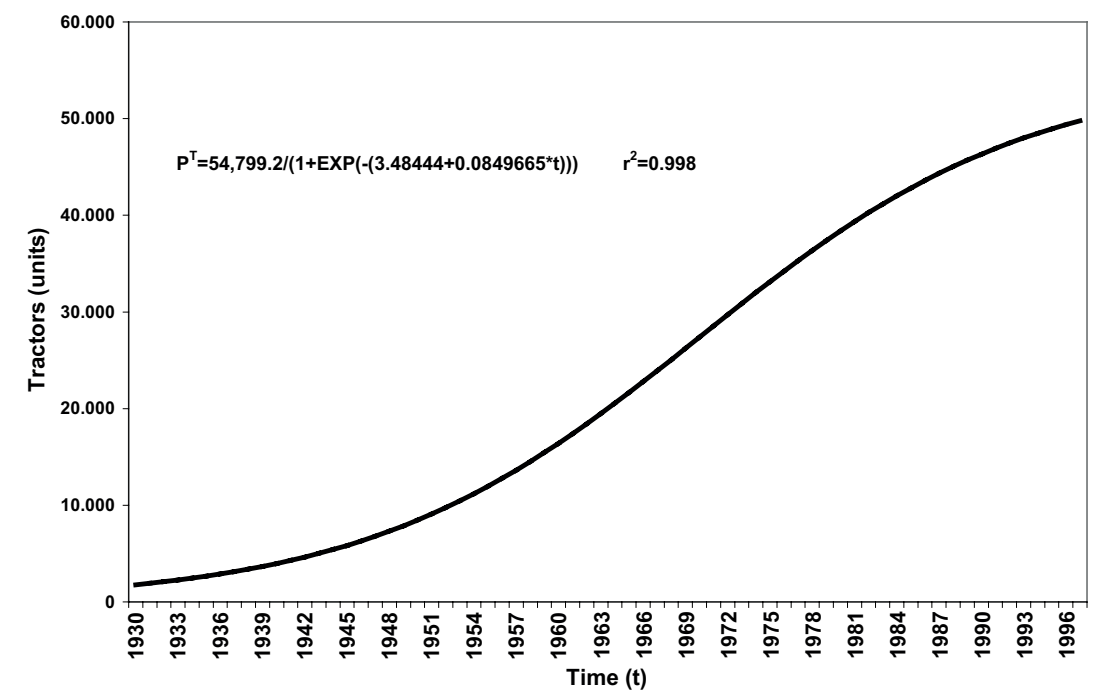

Figure 1. Growth curve of agricultural tractor. 
The average tractor lifespan result obtained in this study is an estimate of the average time that a tractor is kept in operation at the aggregate level, and obviously it is somewhat higher than that used to calculate economic and technical indexes for tractors in Chile (Hetz et al., 1998). However, it should be kept in mind that the success of the procedure used in this study depends on the quality with which the series of tractors enrolled in the RNVM is built each year. With respect to this point, it was observed that for the same year of registration, models manufactured in different years were registered; therefore, the number of units registered in a given year and the number of units manufactured in the same year were not coincident. This creates a dilemma concerning when it is correct to register the inscription. This also introduces variation into the data series, which depends on the thoroughness (of the owners and the entity or entities that regulate the process) with which the units are annually registered in the RNVM, a factor that is beyond the scope of the method used in this study.

On the other hand, the annual growth of the fleet, estimated using equation (2), is based on the nature of the data that were used to develop the model, which were derived from agricultural censuses that, despite determining the actual stock of tractors in the country, is subject (according to the characteristics of the logistic model) to estimates of interpolation areas corresponding to the times between censuses, because it is an accumulated function that also generates a density function. In a recent study (Tomantschger et al., 2011) estimated the probability density function of the lifespan of the engine for a specific tractor model (until an overhaul is needed) may not only be used as a proxy for estimating the tractor lifespan but may also offer a way for further studies to integrate this approach to estimating tractor lifespan at the level of the tractor model cluster within the farm tractor aggregate total.

The proposed model for estimating the fleet of tractors at the aggregate level (the country level), which gives the number of tractors to be incorporated into the stock, $T^{N}$, estimated using equation (1) and based on equation (2), can be useful for market predictions.

The procedure presented provides an option for integrating a fleet balance equation and a model that describes its evolution, but it does not explain the factors that accounted for the evolution, which is a subject that could be studied further.

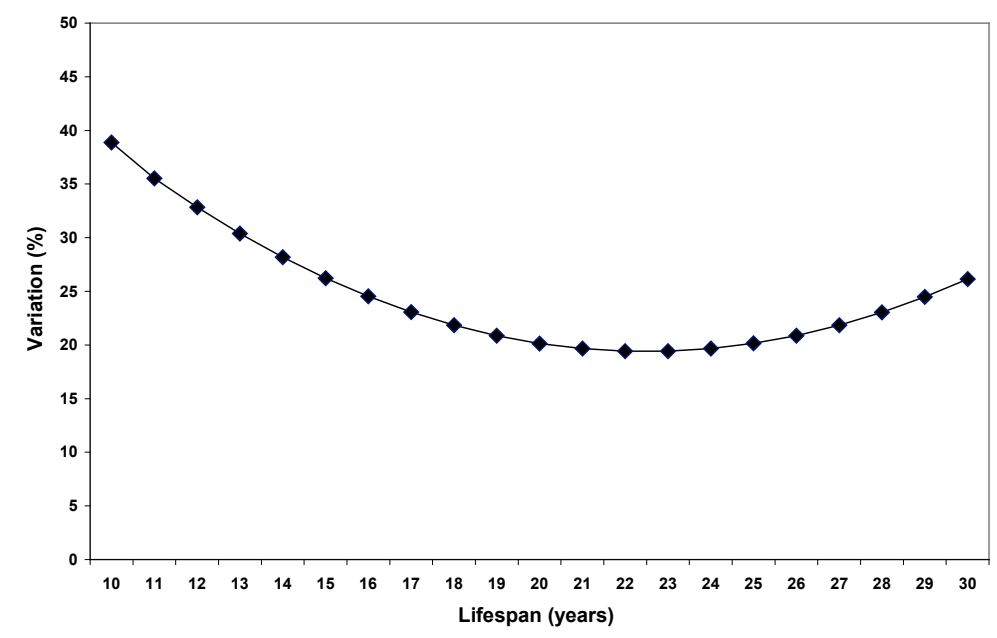

Figure 2. Average variation (\%) between the number of tractors added to the fleet and the number of tractors enrolled annually in the RNVM, assuming a useful life between 10 and 30 years. 


\title{
Resumen
}

\begin{abstract}
R. Muñoz y J. Llanos. 2012. Estimación de la vida útil del tractor agrícola mediante el uso de un modelo de difusión a nivel agregado. Cien. Inv. Agr. 39(3): 557-562. El tractor ha sido icono de cambio tecnológico en la agricultura, su adopción al interior de la explotación agraria ha significado diversas combinaciones, relaciones y formas establecidas de producción de una localidad, región y país. La dinámica del proceso tractorización se encuentra definido por el balance dado por las unidades que ingresan al parque y por aquellas que son resciladas por efecto de término de su vida útil. Este trabajo hace uso del patrón de difusión y adopción agregada del tractor agrícola, cuyos parámetros se determinaron mediante un procedimiento de estimación no lineal, con el empleo de datos a nivel país, en Chile. Utilizando la capacidad de pronóstico del modelo, se estimó una serie longitudinal del parque de tractores y, seguidamente, su balance mediante el cálculo de aquellas unidades que son dadas de baja. Buscando determinar con mayor exactitud la vida útil promedio del tractor, se realizaron sucesivas iteraciones, con objeto de reducir desviaciones cuando se confrontó con una variable control, dada por una serie de tractores inscritos. La vida útil promedio estimada para el tractor agrícola a nivel agregado sería de 22 años. Este procedimiento permitiría ser usado no sólo para fines descriptivos, como en este caso, sino también para propósitos predictivos.
\end{abstract}

Palabras clave: Adopción tecnológica, difusión agregada, mecanización agrícola, tractor agrícola, tractorización, vida útil.

\section{References}

Baptista, R. 1999. The diffusion of process innovations: A selective review. International Journal of the Economics of Business 6:107-129.

Dirección de Estadística y Censos. 1969. IV Censo Nacional Agropecuario, año agrícola 1964-1965. Dirección de Estadística y Censos, República de Chile. Santiago, Chile.

Dirección General de Estadística, 1933. Censo Agropecuario 1929-1930. Dirección General de Estadística, República de Chile. Santiago, Chile. Dirección General de Estadística, 1938. Agricultura 1935/36 Censo. Dirección General de Estadística de Chile. República de Chile. Santiago, Chile.

Duffy M., D. and E. Silberberg. 2006. The diffusion of tractor technology. The Journal of Economic History 66:354-389.

Guadalajara-Olmeda, N., and M.L. Fenollosa-Ribera. 2010. Modelos de valoración de maquinaria agrícola en el Sur de Europa. Un análisis de depreciación real. Agrociencia 44:381-391.

Hetz, E., A. Huerta, S. Villarm, and M. López. 1998. Evaluación económica de los tractores agrícolas comercializados en Chile. Agrosur 26:33-43.
Hussain, A., and F. Ali. 1989. Impact of tractorization on employment and productivity in NWFP. Agricultural University. Peshawar, Pakistan: Institute of Development Studies, NWFP. Agricultural University. $42 \mathrm{pp}$.

INE. 1976. V Censo Nacional Agropecuario 19751976. Instituto Nacional de Estadísticas (INE), Ministerio de Economía, Fomento y Reconstrucción, República de Chile. Santiago, Chile.

INE. 1997. Estadísticas agropecuarias. Instituto Nacional de Estadística, Gobierno de Chile, Santiago, Chile. Available online at: http://www.ine. cl (Website accessed: July 20, 2008).

Mahajan, V., E. Muller, and Y. Wind. 2000. New product diffusion models: From theory to practice. In: Mahajan, V., E. Muller, and Y. Wind. (eds.) New product diffusion models. International series in quantitative marketing. vol. 11. p. 3-24. Boston, Massachusetts: Kluwer Academic Publishers.

Muñoz, R.M, J.L. Llanos, and L.D. Sáez. 2011. Relación entre el parque de tractores agrícolas y el patrón de difusión y adopción mediante un modelo logístico. Información Tecnológica 22(6):121-128.

Olmstead, A.L., and P.W. Rhode. 2001. Reshaping the landscape: The impact and diffusion of the 
tractor in American agriculture, 1910-1960. The Journal of Economic History 61:663-698.

Patel, N.T., and G. Madalsa. 1996. Profile and impacts of tractorization. IIMA Working Papers 1305, Indian Institute of Management Ahmedabad, Research and Publication Department.

Rao, K.U., and V.V.N. Kishore. 2010. A review of technology diffusion models with special reference to renewable energy technologies. Renewable and Sustainable Energy Reviews 14:1070-1078.

Rawlings, J.O., S.G. Pantula, and D.A Dickey (eds.). 1998. Applied regression analysis. A research tool. Second Edition, Springer - Verlag, New York, NY. 486 pp.

Singh, S.K. 2008. The diffusion of mobile phones in India. Telecommunications Policy: 32: 642-651.
SNEC, 1955. III Censo Nacional Agrícola Ganadero. Servicio Nacional de Estadística y Censos, República de Chile. Santiago, Chile.

Tseng, F.M., and Y.C. Hu. 2009. Quadratic-interval Bass model for new product sales diffusion. Expert Systems with Applications 36:8496-8502.

Tomantschger, K.W., Dragan V. Petrović, Zoran D. Golubović, and Zoran I. Mileusnić. 2011. Differential equation model for durability of the tractors engine with application to the model Massey Ferguson 8160. African Journal of Agricultural Research 6:4385-4391.

Unakitan, G., and B. Akdemir. 2007. Tractor demand projection in Turkey. Biosystems Engineering 97:9-25 